\title{
PEDAGOGIA BOŻA W PISMACH OJCÓW KOŚCIOłA
}

Na wstępie należy zaznaczyć, że patrystyczna baza źródłowa, dotycząca problematyki pedagogicznej, jest niezwykle bogata zarówno pod względem ilości przekazów jak i zróżnicowania omawianej problematyki. Mając na uwadze skromne ramy niniejszego opracowania musimy z konieczności skupić się na autorach najbardziej reprezentatywnych, którzy w tytułach swych pism sygnalizują podjęcie problematyki pedagogicznej. Do najwybitniejszych teoretyków pedagogiki katolickiej wczesnego chrześcijaństwa należy niewątpliwie Klemens Aleksandryjski, który ze swymi dziełami: Pedagog ${ }^{1}$ oraz Kobierce ${ }^{2}$ plasuje się na czołowym miejscu, wśród autorów traktujących o kształceniu i wychowaniu, w ujęciu zarówno szczegółowym, jak i globalnym.

Obok niego, wśród greckich Ojców Kościoła miejsce szczególne zajmują: Jan Chryzostom, autor dzieła $O$ próżnej chwale $i$ wychowaniu dzieci ${ }^{3}$ oraz Bazyli Wielki, autor pisma Mowa do młodzieńców, jaki moga odnieść pożytek z czytania ksiqzek pogańskich ${ }^{4}$. Z łacińskich Ojców Kościoła, trudno nie wymienić dwóch Wielkich Doktorów: św. Hieronima oraz św. Augustyna. Pierwszy z nich poświęcił sporo uwagi problematyce wychowania dziewcząt, w liście Do Lety o wychowaniu córki $i^{5}$ oraz w liście Do Gaudencjusza o wychowaniu

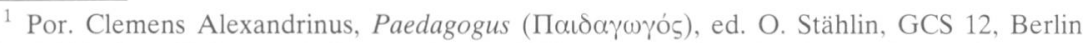
1936, 87-292, thum. T. Puton: Pedagog - Księga I Klemensa Aleksandryjskiego. Wstęp, tłumaczenie, komentarz, Lublin 1977, mps BKUL.

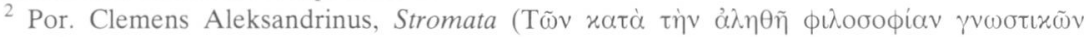

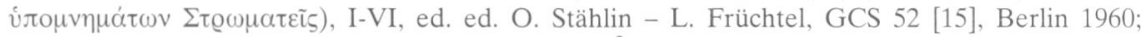
VII-VIII, ed. ed. O. Stählin - L. Früchtel, GCS $17^{2}$, Berlin 1970, thum. J. Niemirska-Pliszczyńska: Kobierce zapisków filozoficznych dotyczących prawdziwej wiedzy, I-II, Warszawa 1994.

${ }^{3}$ Por. Joannes Chrysostomus, De inani gloria et de educandis liberis, ed. A.M. Malingrey, SCh 188, Paris 1972, tłum. W. Kania, w: Sw. Jan Chryzostom, Wybór pism, PSP 13, Warszawa 1974, 157-185, lub: Św. Jan Chryzostom, O małzeństwie, wychowaniu dzieci i ascezie, BOK 19, Kraków 2002, 73-105.

${ }^{4}$ Por. Basilius Caesariensis, Oratio ad adolescentes de legendis libris gentilium, PG 31, 563-590, tłum. T. Sinko, w: Św. Bazyli Wielki, Wybór homilij i kazań, Kraków 1947, 213-230.

5 Por. Hieronymus, Epistula 107 (Ad Laetam de institutione filiae), ed. I. Hilberg, CSEL 55, Vindobonae 1910, 290-305, tłum. J. Czuj: Sw. Hieronim, Listy, II, Warszawa 1953, 400-414. 
młodziutkiej Pakatuli ${ }^{6}$. Z pism św. Augustyna, dotyczących problematyki pedagogicznej, na szczególną uwagę zasługują dwa traktaty filozoficzne: $\mathrm{O}$ nauczycielu $u^{7}$ oraz $O$ porzadku ${ }^{8}$, a także dzieło Poczatkowe nauczanie religii ${ }^{9}$.

Termin $\pi \alpha \iota \delta \alpha \gamma \omega \gamma i \alpha$ (złożony z dwóch rzeczowników: $\pi \alpha \tilde{s}$ - dziecko, $\alpha \gamma(\omega \gamma \eta \dot{n}$ - prowadzenie, kierowanie) pojawia się po raz pierwszy w literaturze wczesnochrześcijańskiej, w wyżej wspomnianym dziele Klemensa Aleksan-

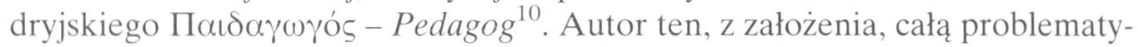
kę pedagogiczną grupuje wokół dwóch kluczowych bliskoznacznych terminów, którymi są rzeczowniki: $\pi \alpha \iota \delta \alpha \gamma \omega \gamma i \alpha$ oraz $\pi \alpha \iota \delta \varepsilon i \alpha^{11}$. Termin $\pi \alpha \iota \delta \varepsilon i \alpha$ pojawia się w literaturze klasycznej już od V wieku przed Chrystusem, m.in. w pismach Ajschylosa, Arystofanesa, Platona oraz Arystotelesa ${ }^{12}$. Klemens Aleksandryjski terminem $\pi \alpha \iota \delta \varepsilon i \alpha$ określa zarówno proces wychowania i kształcenia, jak i jego wyniki: wiedzę, wykształcenie, kulturę intelektualną, kulturę moralną oraz dyscyplinę ducha ${ }^{13}$.

Rysem charakterystycznym Klemensowej pedagogiki, który przeniknie do całej późniejszej literatury patrystycznej, jest ujęcie teocentryczne oraz chrystocentryczne całego procesu wychowania i kształcenia. Wymownym przejawem tych tendencji są następujące zwroty, występujące w pismach Klemen-

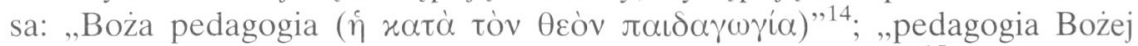

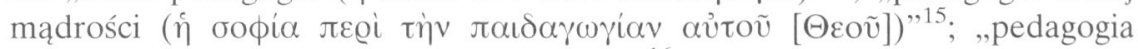

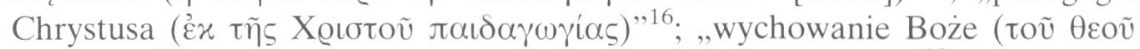

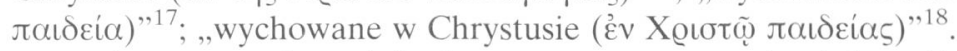

Mając na uwadze założenia teoretyczne oraz całą złożoność tematyki pedagogicznej, Klemens Aleksandryjski plasuje zagadnienia z nią związane

${ }^{6}$ Por. Hieronymus, Epistula 128 (Ad Gaudentium de institutione Pacatulae), ed. I. Hilberg, CSEL 56, Vindobonae 1918, 156-162, thum. J. Czuj, III, Warszawa 1954, 286-293.

${ }^{7}$ Por. Augustinus Hipponensis, De magistro, PL 32, 1193-1220, lub CCL 29, Turnhout 1970, 151-203, tłum J. Modrzejewski, w: Św. Augustyn, Dialogi filozoficzne, t. 3, Warszawa 1953, 18-70; lub Św. Augustyn, Dialogi filozoficzne, Kraków 2001, 433-485.

${ }^{8}$ Por. Augustinus Hipponensis, De ordine, PL 32, 977-1020, lub CCL 29, 87-137, thum. W. Seńko, w: Św. Augustyn, Dialogi filozoficzne, t. 1, Warszawa 1953, 146-226; lub Św. Augustyn, Dialogi filozoficzne, Kraków 2001, 155-234.

9 Augustinus Hipponensis, De catechizandis rudibus, PL 40, 309-348, lub CCL 46, 121-178, tłum. W. Budzik, w: Św. Augustyn, Pisma katechetyczne, POK 10, Poznań 1929, 1-71.

${ }^{10}$ Por. Clemens, Paedagogus I 12, 1; 16, 1; 54, 1; 74, 3; 99, 2.

11 Por. tamże I 16, 1.

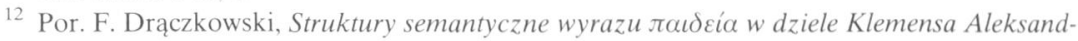
ryjskiego $\Sigma \tau \varrho \omega \mu \alpha \tau \varepsilon \tilde{\varsigma}$, w: Z zagadnień literatury greckiej, red. J. Pliszczyńska, Lublin 1978, 127-151.

13 Por. tamze, s. 130-131.

14 Clemens, Paedagogus I 54, 1, GCS 12, 122.

15 Tamże 74, 3, GCS 12, 133.

16 Tamże 99, 2, GCS 12, 149.

17 Clemens, Stromata I 32, 2, GCS 52, 21.

18 Tamże IV 108, 4, GCS 52, 296. 
w pięciu grupach problemowych, czego świadectwem jest następująca wypowiedź o charakterze ogólno-problemowym:

„Termin pedagogia ( $\pi \alpha \iota \delta \alpha \gamma \omega \gamma i \alpha)$ odnosi się do rzeczywistości złożonej: najpierw dotyczy tego, który jest prowadzony (kierowany) i uczy się, potem tego, który prowadzi (kieruje) i uczy; po trzecie, odnosi się do samego procesu prowadzenia (kierowania) oraz - po czwarte - do tego, co jest przedmiotem nauczania, np. poleceń. Boska zaś pedagogia ukazuje drogę prawdy prowadzącą do kontemplacji Boga oraz wzory świętych działań w wiecznym przebywaniu"19.

Jak wynika z powyższej wypowiedzi, pedagogika katolicka, zdaniem Klemensa, traktuje o: 1. wychowankach; 2. wychowawcach; 3. procesie prowadzenia (kierowania), tj. o metodzie; 4. programie formacji intelektualnej oraz moralnej, nadto 5. o celu całego procesu formacyjnego.

1. Szkoła Boskiego Logosu - Kościół. Pod koniec III księgi Pedagoga, jakby w podsumowaniu, Klemens Aleksandryjski zamieszcza wypowiedź kluczową dla całej swej wizji pedagogiki katolickiej:

„Szkołą jest Kościół, a jedynym Nauczycielem - Oblubieniec, dobra Wola Dobrego Ojca, Mądrość prawdziwa”"20.

W słowach tych Klemens nawiązuje do instytucji dobrze znanej i wysoko cenionej tak w starożytności przedchrześcijańskiej, jak i chrześcijańskiej, jaką

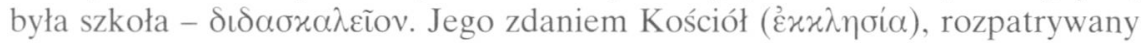
w aspekcie formacyjnym, nosi wszystkie znamiona szkoły. Kościół jest szkołą -

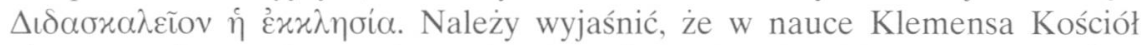
ujmowany jest w kategoriach eklezjologii św. Pawła. Głową Kościoła jest Chrystus, którego Ciałem jest lud Boży. Głowa zespolona z Ciałem, tworzy jeden organizm, który Klemens określa „Kościołem katolickim ( $x \alpha \theta 0 \lambda \iota x \grave{~}$

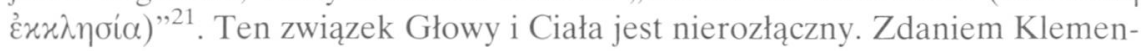
sa, my, wierzący w Chrystusa, lud Boży:

„wtedy stajemy się doskonali, kiedy jesteśmy Kościołem, ponieważ przyjęliśmy Chrystusa, który jest jego Głową"22.

Według Klemensa, ,Kościół, podobnie jak człowiek, złożony jest z wielu członków"23. Cały człowiek to głowa i ciało razem złączone. Cały Kościół to lud Boży - Ciało Chrystusa, i Chrystus - Głowa, razem zespolone w jeden organizm. Warto zaznaczyć, że nauka powyższa koresponduje z doktryną eklezjologiczną

\footnotetext{
${ }^{19}$ Clemens, Paedagogus I 54, 1, GCS 12, 122.

20 Tamże III 98, 1, GCS 12, 289.

21 Por. Clemens, Stromata VII 107, 5, GCS 17, 76.

22 Clemens, Paedagogus I 18, 4, GCS 12, 101; por. Ef 1, 22; 5, 23; Kol 1, 18.

23 Tamże I 38, 3, GCS 12, 113.
} 
św. Augustyna, przyjętą przez Katechizm Kościoła Katolickiego: „Chrystus i Kościół tworzą, więc «całego Chrystusa» (Christus Totus) ${ }^{24}$.

W Kościele, który jest szkołą Chrystusa, Boskiego Logosu, realizuje się cały proces formacji pedagogicznej; Chrystus - Głowa jest dla swego Ciała - ludu Bożego ,,jedynym prawdziwym wychowawcą i nauczycielem”25; wychowankami tej szkoły są wszyscy wierzący w Chrystusa - lud Boży; Boski Logos, który kieruje swą szkołą - Kościołem, posługuje się najlepszymi metodami pedagogicznymi; On też jest twórcą całego programu zmierzającego ku pełnemu doskonaleniu całego człowieka, którego celem jest zbawienie. Wizja pedagogiczna Klemensa jest na wskroś eklezjalna.

2. Alumni Szkoły Boskiego Logosu - lud Boży. W nauce Klemensa Aleksandryjskiego dobitnie została uwypuklona idea uniwersalizmu ludu Bożego. Wychowankami Szkoły Logosu - Kościoła są bowiem nie tylko wszyscy ochrzczeni, ale również wszyscy ludzie sprawiedliwi. Według Klemensa „w poczet

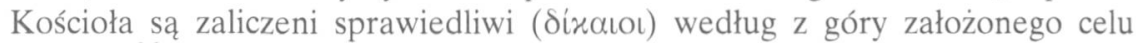
Bożego" 26. Kościół „skupia tych wszystkich, którzy już są doń przydzieleni, a których wybrał Bóg z góry, przed stworzeniem świata, wiedząc, że będą sprawiedliwi" ${ }^{27}$. Warto zauważyć, że w takim postawieniu sprawy przynależności do ludu Bożego, Klemens staje się prekursorem nauki Soboru Watykańskiego II, który poucza, że do ludu Bożego mogą być przyporządkowani wszyscy ludzie dobrej woli, ,którzy szczerym sercem szukają Boga i wolę Jego poprzez nakaz sumienia poznaną, starają się pod wpływem łaski pełnić czynem"28.

Wychowankami Szkoły Boskiego Logosu, Szkoły Chrystusowej, są zatem ci wszyscy, którzy przynależą do Ludu Bożego, niezależnie od grupy wiekowej, to jest, zarówno dzieci, młodzież, jak i wszyscy dorośli. Klemens przypomina, że wszyscy alumni Szkoły Logosu, nazywani są „dziećmi”29. W Piśmie Świętym Bóg jest określany jako Ojciec wszystkich ludzi - wszystkich wierzących ( Rz 1, 7; 1Kor 1, 3; Flp 1, 2). Stąd określenie „dzieci” odnoszone jest do statusu wszystkich wierzących, którzy nazywani są „dziećmi Bożymi” (J 1, 12; Rz 8, 16), „dziećmi umiłowanymi” (Ef 5,1). Dziecko jest na etapie wzrostu i dojrzewania. Wszyscy wierzący, alumni Szkoły Chrystusowej, są wezwani do „wzrostu na miarę dojrzałości Chrystusowej” (Ef 4, 13). Stąd zdaniem Klemensa określenie wszystkich wychowanków Szkoły Boskiego Logosu jako „dzieci”, zdaje się być w pełni uzasadnione ${ }^{30}$.

\footnotetext{
${ }^{24}$ KKK 795; por. Augustinus, In Evangelium Johannis tractatus 21, 8.

25 Clemens, Paedagogus I 10, 2, GCS 12, 96; por. też I 97, 1; III 98, 1.

${ }^{26}$ Clemens, Stromata VII 107, 3, GCS 17, 76, Niemirska-Pliszczyńska II 306.

27 Tamże 107, 5, GCS 17, 78, Niemirska-Pliszczyńska II 306.

28 Konstytucja dogmatyczna o Kościele „Lumen pentium” 16; por. KKK 954.

29 Por. Clemens, Paedagogus I 12, 1, GCS 12, 96.

${ }^{30}$ Por. tamże I 12, 1; 14, 5; III 99, 1.
} 
Z uwagi na stopień zaawansowania w procesie doskonalenia, alumni Szkoły Logosu, zdaniem Klemensa, mogą być zaszeregowani do trzech grup. Do pierwszej grupy, najmniej zaawansowanych, należą grzesznicy o zatwardziałych

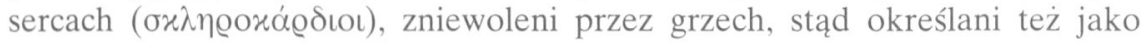

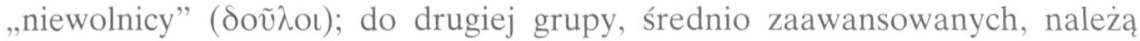

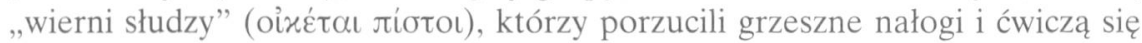
w cnotach; do trzeciej grupy, najbardziej zaawansowanych należą przyjaciele Chrystusa ( $\phi$ í̀o ), którzy przez doskonałą miłość upodobnili się do Boga ${ }^{31}$.

Wszyscy wyżej wymienieni, są wychowankami Szkoły Chrystusowej, którą jest Kościół, niezależnie od stopnia postępu na drodze doskonalenia, jak i statusu społeczno-rodzinnego oraz wiekowego: dzieci i rodzice, młodzieńcy i starcy, grzesznicy i święci, nawracający się oraz wierni słudzy, dążący do doskonałości oraz przyjaciele Boga. Tej uniwersalnej wizji alumnów Boskiego Logosu, w tym wymiarze co u Klemensa, nie znajdujemy w pedagogii innych ojców Kościoła. Jan Chryzostom pisząc o wychowankach ma na uwadze okres od wczesnego dzieciństwa do czasu narzeczeństwa i zaślubin. Wychowankami są zarówno małe dzieci (chłopcy i dziewczęta) do lat ośmiu, jak i w wieku dojrzewania do lat piętnastu oraz młodzież dojrzała do małżeństwa ${ }^{32}$.

3. Boski Logos wychowawcą Ludu Bożego. W wizji Klemensa Aleksandryjskiego wychowawcą najdoskonalszym $\mathrm{i}$, w istocie rzeczy jedynym, jest od-

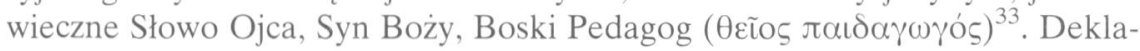
ruje to wyraźnie w słowach:

„naszym Pedagogiem jest święty Bóg, Jezus, przewodnik całej ludzkości (ó đáơ

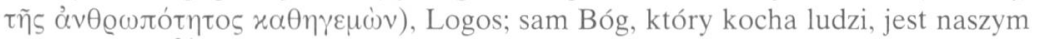
Pedagogiem"34.

Boski Logos jest wychowawcą wszystkich ludzi w wymiarze uniwersalnym; wychowawcą zarówno ludu starego, jak i nowego. Według Klemensa:

„Dawniej przez Mojżesza Bóg sprawował funkcję wychowawcy, następnie przez proroków"35;

„Był bowiem Pan rzeczywiście Pedagogiem starego ludu przez Mojżesza”36;

„On sam też poucza Mojżesza, jak być pedagogiem”37.

${ }^{31}$ Por. Clemens, Stromata I 173, 6; VII 5, 6; zob. F. Drączkowski, Kościót-Agape według Klemensa Aleksandryjskiego, Lublin 1983, 136-158 (Kościół jako szkoła Logosu).

${ }^{32}$ Por. Joannes Chrysostomus, De educandis liberis 52 i 81-82.

${ }^{33}$ Por. Clemens, Paedagogus I 75, 1; 81, 1; 97, 3; 100, 2.

34 Tamże I 55, 2, GCS 12, 123.

35 Tamze I 96, 3, GCS 12, 147.

36 Tamże I 58, 1, GCS $12,124$.

37 Tamże I 57, 3 GCS 12, 124. 
Zdaniem Klemensa Boski Logos przez filozofię, którą dał Hellenom ${ }^{38}$, stał się pośrednio ich wychowawcą. Aleksandryjczyk mówiąc o filozofii ma na uwadze tylko tę, która jest „zgodna z Boskim Logosem” "39. W ten sposób filozofia stała się dla Hellenów jakby „trzecim Testamentem” ${ }^{40}$. Boski Logos stał się wychowawcą tak Hebrajczyków jak i Hellenów, którzy łączą się w jedną społeczność Ludu Bożego:

„Oto łączą się wychowankowie kultury helleńskiej z wychowankami prawa judejskiego w jedną społeczność zbawianego ludu, jako wyznawcy jednej wiary. Ale to nie są trzy ludy oddzielone czasem tak, że trzeba by przyjąć, trzy natury odrębne, lecz przez różne przymierza jednego Pana wychowywane, ale będące pod działaniem słowa Pana Jedynego" ${ }^{41}$.

Charakterystyka Boskiego Wychowawcy została przedstawiona przez Klemensa w I księdze Pedagoga. Jako Bóg jest On „najlepszym wychowawcą

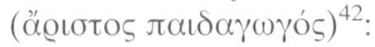

„Boski Pedagog ozdobiony jest trzema najpiękniejszymi przymiotami: wiedzą, życzliwością i autorytetem. Wiedzą, ponieważ jest Mądrością Ojca: «cała mądrość od Boga pochodzi, jest z Nim na wieki» (Syr 1, 1). Autorytetem, gdyż jest Bogiem i Stwórcą: «Wszystko przez Niego się stało, a bez Niego nic się nie stało» (J 1, 3). Życzliwością, bowiem sam wydał siebie na ofiarę za nas: «Dobry pasterz daje życie swoje za owce» $(\mathrm{J} 10,11)$ i On rzeczywiście je złożył"43.

„Boski Pedagog jest ,jedynym i prawdziwym wychowawcą"44.

Dopełnieniem powyższej charakterystyki są przymioty i cechy, które Kle-

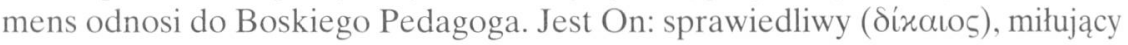

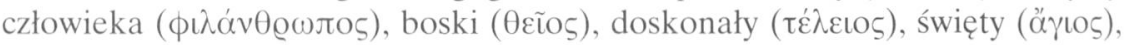

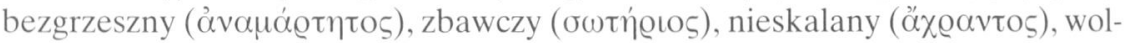

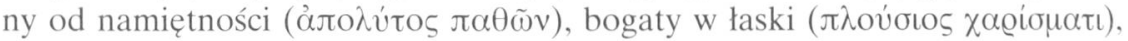

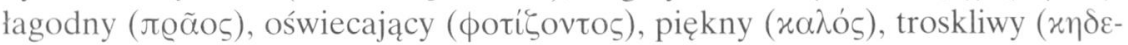

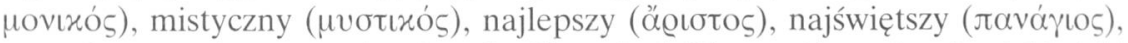

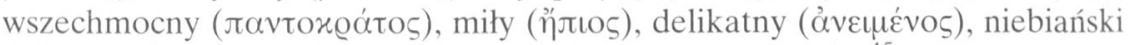

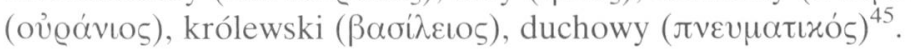

38 Por. Clemens, Stromata I 20, 1; 28, 2.

39 Por. tamze I 90, 1.

${ }^{40}$ Por. tamże IV 46, 6; zob. J.T. Muckle, Clement of Alexandria on Philosophy as Divine Testament for the Greeks, „Phoenix” 5 (1951) 79-86.

${ }^{41}$ Clemens, Stromata VI 42, 1 GCS 52, 454, Niemirska-Pliszczyńska II 135.

42 Clemens, Paedagogus I 62, 2, GCS 12, 126.

43 Tamże I 97, 3, GCS 12, 148.

44 Tamże I 10, 2, GCS 12, 96; por. też 97, 1.

45 Por. tamże I 17, 2; 55, 2; 75, 1; 25, 3; 6, 1; 4, 1; 60, 3; 4, 2; 6, 4; 15, 2; 51, 3; 53, 2; 59, 1; 62, 2; 84 , $1 ; 37,3 ; 1,3 ; 22,3 ; 41,3 ;$ por. F. Drączkowski, Szkic chrystologii Klemensa Aleksandryjskiego w świetle onomastyki pierwszej księgi „Pedagoga”, VoxP 4 (1984) z. 6-7, 101-125. 
Mając na uwadze etymologię terminu $\pi \alpha \iota \delta \alpha \gamma \omega \gamma i \alpha$, w szczególności zaś jego drugi człon - $\alpha \hat{\gamma} \omega \gamma \eta$, który oznacza: prowadzenie, kierowanie, Klemens stosuje szereg nazw synonimicznych, do określenia $\pi \alpha \iota \delta \alpha \gamma \omega \gamma o ́ s$, które oznaczają różnorodność funkcji kierującej, czy też ,prowadzącej”, Boskiego Logosu. Z tej racji nawiązuje do biblijnego określenia Chrystusa - Dobrego Pasterza (J 10, 11). Charakteryzując Boskiego Wychowawcę, pisze:

„Pozostaje nam jeszcze wyjaśnić, kim jest nasz Pedagog. Nazywa się Jezus. Często nazywa siebie pasterzem i mówi: «Ja jestem Dobrym Pasterzem» (J 10, 11). Zgodnie z metaforą wziętą od pasterzy prowadzących owce, Pedagogiem określany jest ten, kto jest przewodnikiem dzieci, kto jest troskliwym pasterzem niemowląt. Proste niemowlęta alegorycznie nazywane są owcami. Mówi: «Staną się wszyscy jedną owczarnią i jednym Pasterzem». Syn Boży słusznie nazywa się Pedagogiem, gdyż prowadzi nas, dzieci, do zbawienia"46.

Z racji funkcji kierowniczej, Boski Pedagog bywa też określony jako „Boski

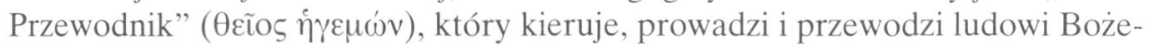
mu na wszystkich etapach drogi doskonalenia. Jeden lud Boży, jak wyżej wspomniano, z uwagi na stopień zaawansowania w procesie doskonalenia, dzieli się na trzy grupy: grzeszników, czyli chorych duchowo, wiernych sług i przyjaciół. Boski Przewodnik, kierownik tej Szkoły, którą jest Kościół, wobec każdej z wyżej wymienionych grup, pełni kolejno różne funkcje: Lekarza, który wyprowadza grzeszników z niewoli grzechu, Wychowawcy, który ćwiczy wierne sługi w cnocie oraz Nauczyciela, który poucza treścią tajemnic ludzi dojrzałych ${ }^{47}$.

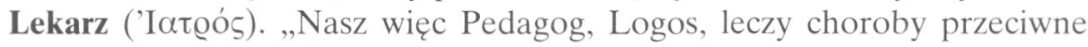
naturze naszej duszy [...]. Dobry zaś Pedagog, który jest Mądrością, Synem Ojca, Stwórcą człowieka, troszczy się o całego człowieka, leczy jego ciało i duszę. Jest On Lekarzem całej ludzkiej natury"48.

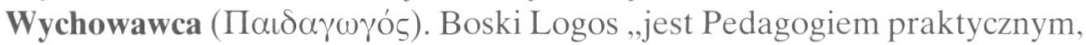
a nie teoretycznym, dlatego ma na celu ulepszać duszę, a nie pouczać; kierować do życia roztropnego, a nie poznawczego [...] najpierw zachęcił nas do ukształtowania obyczajów, teraz zaś wzywa do spełnienia obowiązków [...] pedagog prowadzi dzieci ku zbawczemu trybowi życia, przejęty troską o nie" 49 .

Nauczyciel $(\Delta \mathrm{\iota} \delta \alpha \dot{\sigma} x \alpha \lambda \circ \varsigma)$, „Logos, który jest również Nauczycielem [...] odsłania prawdy teoretyczne, dogmatyczne" ${ }^{, 50}$. Czyni to tylko wobec przyjaciół, zwanych również gnostykami, którzy w Szkole Logosu doszli do najwyższego etapu: „Oto nauczyciel, który gnostyka wychowuje treścią tajemnic”51.

\footnotetext{
${ }^{46}$ Clemens, Paedagogus I 53, 2-3, GCS 12, 121-122; por. J 10, 11, 14 i 16.

${ }^{47}$ Por. Clemens, Stromata I 173, 6; VII 5, 6.

${ }^{48}$ Clemens, Paedagogus I 6, 1-2, GCS 12, 93.

49 Tamże I 1, 4-2, GCS 12, 90; por. też I 54, 2.

50 Tamże I 2, 1, GCS 12, 90.

${ }^{51}$ Clemens, Stromata VII 6, 1, GCS 17, 6, Niemirska-Pliszczyńska II 221.
} 
Mając na uwadze trzy powyższe funkcje Boskiego Logosu, Klemens, jakby w podsumowaniu, stwierdza:

„Bardzo życzliwy Logos, starając się udoskonalić nas przez stopniowe wzrastanie, oparte na skutecznym wychowaniu, kieruje się piękną zasadą: najpierw nawraca [leczy], następnie wychowuje i w końcu naucza"52.

4. Pedagogiczny personel pomocniczy Szkoły Boskiego Logosu. Zdaniem Klemensa Aleksandryjskiego, kontynuatorami misji wychowawczej Boskiego Logosu, są alumni „trzeciej grupy” Szkoły Logosu, przyjaciele Chrystusa, zwani też gnostykami. Mają oni udział zarówno w funkcji „leczniczej”, jak i wychowawczej oraz nauczycielskiej Boskiego Pedagoga ${ }^{53}$. Na kanwie tego stwierdzenia, rodzi się pytanie, kogo Klemens miał na myśli, mówiąc o przyjaciołach Chrystusa - gnostykach? Czy do tej grupy zaliczał również diakonów, prezbiterów i biskupów? W pismach Klemensa znajdujemy wyraźne potwierdzenie istnienia w Kościele jego czasów, trójstopniowej hierarchii:

„,[...] istniejące tu na ziemi w Kościele stopnie hierarchiczne: biskupów, prezbiterów, diakonów, są naśladownictwem, jak sądzę, wspaniałości anielskiej i owej ekonomii zbawienia, której mogą oczekiwać, wedle słów Pisma Świętego, ludzie, których życie upłynęło w pełni sprawiedliwości, zgodnie z Ewangelią, wedle śladu stóp apostolskich" ${ }^{\text {" }}$.

Rzecz charakterystyczna, pełnienie funkcji wychowawczych w Kościele, Klemens skłonny jest przyznać zarówno prezbiterom, jak i przyjaciołom Boga - gnostykom. Świadectwo tej zasady, znajdujemy w następującej wypowiedzi:

„Służba Boża dla gnostyka polega zatem na bezustannej dbałości o własną duszę i na pielęgnacji w sobie tego, co boskie, pielęgnacji wyrosłej z nieprzerwanej nigdy miłości. Natomiast dbałość jego o ludzi dwojaki ma charakter: albo ulepszający, albo służebny. Ulepszaniem na przykład ciała zajmuje się sztuka lekarska, ulepszeniem zaś duszy - filozofia. Rodzicom od dzieci, zwierzchnikom od podwładnych należy się pomoc służebna. Podobnie i w Kościele funkcję ulepszającą obrazują prezbiterzy, służebną zaś - diakoni. Obydwie te funkcje pełnią też aniołowie u boku samego Boga, w zakresie zarządu sprawami ziemskimi. Pełni je również i gnostyk, który z jednej strony służy Bogu, z drugiej zaś - przekazując ludziom swój światopogląd działa na nich ulepszająco, jako że zostało mu powierzone i zadanie wychowawcze ku naprawie ludzi" ${ }^{\prime 55}$.

Dalsza kwestia dotyczy istoty urzędu prezbitera i jego weryfikacji. W tej sprawie Klemens zajmuje dość nietypowe stanowisko, gdy pisze:

\footnotetext{
52 Clemens, Paedagogus I 3, 3, GCS 12, 91.

53 Por. Clemens, Stromata VII 52, 1-3; 53, 1-6.

54 Tamże VI 107, 2-3, GCS 52, 485, Niemirska-Pliszczyńska II 176.

55 Tamże VII 3, 1-4, GCS 17, 4, Niemirska-Pliszczyńska II 218-219.
} 


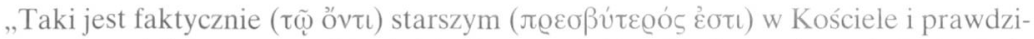
wym sługą (diakonem) woli Bożej, jeśli sam pełni i wykłada przykazania Boże. I nie dlatego uważany jest za sprawiedliwego, że przez ludzi został wybrany, i także nie dlatego, że jest on starszy (

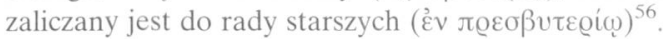

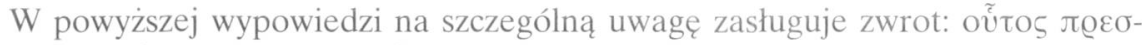

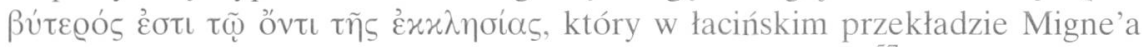
został oddany słowami: „Hic est revera presbyter Ecclesiae”, , a w przekładzie włoskim: „Ed è realmente un «anziono» della Chiesa" 58 .

Zatem: prawdziwie, faktycznie, realnie, rzeczywiście, ten jest prezbiterem w Kościele, kto żyje według przykazań Bożych i je wykłada; kto jest „sprawiedliwy" ( lub że nie został wybrany. Wybór nie odgrywa tu istotnego znaczenia. Liczą się fakty: życie zgodne z Ewangelią i nauczanie prawd Bożych. Według Klemensa takimi osobami są święci, przyjaciele Boga - gnostycy. Należy wyjaśnić, że w wykładzie Klemensa termin ,gnostyk" jest określeniem synonimicznym do „,człowieka doskonałego”. Prawdziwi gnostycy według Klemensa są „mężami doskonałymi w miłości do Boga"59, „mężami w pełni sprawiedliwymi" „,którzy żyli w sposób doskonały według Ewangelii”" . Do gnostyka Klemens stosuje określenie: „,wzniosły Boży kapłan”62. Ogólną charakterystykę człowieka doskonałego (gnostyka) znajdujemy w następującej wypowiedzi Klemensa:

„Nasz gnostyk jest więc jedynym człowiekiem, który do późnego wieku trwa w badaniu współczesnych Pism Kościoła, oraz kontynuuje ścisłą wierność (por. 2 Tm 2, 15) apostolskiego i kościelnego wkładu zasad wiary oraz żyje jak najściślej według Ewangelii, doznając natchnienia od Pana, aby mógł znaleźć, począwszy od Pana i proroków, argumenty, których szuka. Życie bowiem gnostyka jest, jak sądzę, niczym innym jak działaniem i słowem zgodnym z przekazem Pana" ${ }^{2}$.

Analizując powyższe wypowiedzi, nietrudno zauważyć, że gnostyk który bada pisma, naucza zgodnie z nauką apostołów i Kościoła oraz żyje zgodnie z Ewangelią, według Klemensa, jest „rzeczywiście prezbiterem w Kościele”, nawet wtedy, gdy nie został powołany do tej godności. Na kanwie powyzszych wypowiedzi F. Hofmann stwierdza krytycznie, że Klemens mówiąc o biskupach nigdzie nie wspomina, że ich zadaniem jest przekaz nauki wia-

\footnotetext{
56 Tamże VI 106, 2, GCS 52, 485, Niemirska-Pliszczyńska II 175.

57 PG 9, 327.

58 Por. przekład G. Pini, w: Clemente Alessandrino, Stromati, Milano 1985, 732.

59 Clemens, Stromata VII 67, 2, GCS 17, 48, Niemirska-Pliszczyńska II 271.

60 Tamże VI 107, 2, GCS 52, 485, Niemirska-Pliszczyńska II 176.

61 Tamże VI 106, 1, GCS 52, 485, Niemirska-Pliszczyńska II 175.

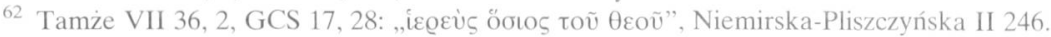

63 Tamże VII 104, 1-2, GCS 17, 73, Niemirska-Pliszczyńska II 303.
} 
ry. Wspomniany autor zaznacza, że wprawdzie Klemens mówi o Kościele założonym przez apostołów oraz o biskupach, którzy zostali ustanowieni przez apostołów przełożonymi poszczególnych wspólnot, milczy jednak na temat ich funkcji nauczycielskiej, co więcej, funkcję przekazu doktryny wiary, przyznaje gnostykom ${ }^{64}$. Idąc dalej, F. Hofmann w wypowiedziach Aleksandryjczyka dopatruje się ukrytej opozycji wobec współczesnej mu hierarchii kościelnej ${ }^{65}$.

Z tym stanowiskiem można by polemizować. Z wypowiedzi Klemensa wynika, że jego intencją nie było wprowadzanie antagonizmu między hierarchami i gnostykami. Wręcz przeciwnie. Wszystko, co Klemens na ten temat pisze, wskazuje na ukryty postulat, aby z grona gnostyków byli wybierani biskupi, prezbiterzy i diakoni. Mając na uwadze całość eklezjologii Aleksandryjczyka ${ }^{66}$ można powiedzieć, że wyróżniał on dwie hierarchie paralelne w Kościele: hierarchię doskonałości i hierarchię urzędu. Zakresy obu tych hierarchii mogły, ale nie musiały się pokrywać. Dlaczego Klemens stawiał w Kościele bardziej na hierarchię doskonałości? Dlatego, że jej zakres był o wiele szerszy niż tej drugiej. Z grona gnostyków tylko niektórzy otrzymali urzędy w Kościele. Pozostała reszta stanowić miała w Kościele „zdrowy zaczyn”, „elitę laikatu” - żeby wyrazić się adekwatnie do terminologii Vaticanum II. Przerzucenie ciężaru odpowiedzialności za Kościół wyłącznie na barki hierarchów znacznie by Kościół osłabiło. Jeśli Klemens mówi o odpowiedzialności gnostyków za Kościół, to domyślnie mówi o gnostykach biskupach, prezbiterach i diakonach oraz o gnostykach nie wchodzących w skład hierarchii. Zakres pojęcia "gnostycy” jest o wiele szerszy niż zakres określenia „hierarchia kościelna". Klemensowy ideał prawdziwego gnostyka jest też ideałem prawdziwego kapłaństwa. Na temat gnostyka istnieje obszerna literatura. Wśród studiów, które zwracają szczególną uwagę należy na pierwszym miejscu wymienić monumentalne dzieło (liczące ponad 700 stron) W. Völkera ${ }^{67}$, następnie prace: P. Dudona ${ }^{68}$, C. Guasco ${ }^{69}$, J. Grzywaczewskiego ${ }^{70}$.

${ }^{64}$ Por. F. Hofmann, Die Kirche bei Clemens von Alexandrien, w: Vitae et Veritati. Festgabe für Karl Adam, Düsseldorf 1956, 15; zob. Clemens, Stromata IV 75, 1; tenże, Quis dives salvetur 42, 2. 8 .

${ }^{65}$ Por. Hofman, Die Kirche bei Clemens von Alexandrien, s. 16: „Man wird schwerlich annehmen können, dass dieses beharrliche Schweigen über das bischöfliche Lehramt nur rein zufäligen Natur ist; vielmehr legt sich der Gedanke nahe, dass Clemens die Funktion der unversehrten Weitergabe der Überliferung eher dem Gnostiker als dem kirchlichen Amtsträger zuerkannte".

66 Por. Drączkowski, Kościót - Agape, s. 136-158 (Kościół jako szkoła Logosu).

67 Por. Der wahre Gnostiker nach Clemens Alexandrinus, Berlin 1952.

68 Por. Le gnostique de Saint Clément d'Alexandrie, Paris 1930.

69 Por. Lo gnostico cristiano in Clemente Alessandrio, ,Sophia” 24 (1956) 262-269.

70 Por. Obraz gnostyka według „Stromatów” Klemensa Aleksandryjskiego, VoxP 6 (1986) z. $11,543-554$. 
Zdaniem Klemensa gnostycy, którzy nie zostali wyróżnieni urzędem w Kościele ziemskim, zostaną nim obdarzeni w Kościele niebieskim:

„A jeśli tu na ziemi nie zostanie on [gnostyk] zaszczycony pierwszym miejscem (por. Mt 23, 6; Mk 12, 39: Łk 11, 43; 20, 46), to zasiądzie na jednym z dwudziestu czterech tronów i będzie sądził lud, jak mówi Jan w Apokalipsie (por. Ap 4, 4) ${ }^{71}$ [...]. O nich [gnostykach] pisze Apostoł, że ci, uniesieni «na obłokach» (por. 1Tes 4, 17), będą najpierw diakonami, z kolei zaliczeni zostaną do rady prezbiterów, wedle wyższego stopnia czci (bo między czcią a czcią jest jeszcze różnica), aż urosną do «ideału człowieka w pełni doskonałego»"72.

Znamienny jest tytuł trzynastego rozdziału VI księgi Stromatów: „O tym, że dla ludzi prawdziwie doskonałych są zastrzeżone w niebie stopnie chwały, odpowiadające stopniom biskupa, prezbitera i diakona w Kościele ziemskim"73.

W świetle powyższych dywagacji można powiedzieć, że zdaniem Klemensa Aleksandryjskiego, udział w misji pedagogicznej Boskiego Logosu mają ci wszyscy, którzy osiągnęli status przyjaciół Boga. Mogą być nimi zarówno przedstawiciele hierarchii kościelnej, to jest: biskupi, prezbiterzy i diakoni, jak i ci wszyscy przedstawiciele laikatu, którzy przez doskonałą miłość w pełni upodobnili się do Boskiego Logosu.

Natomiast Jan Chryzostom, w sposób tylko pośredni, nawiązuje do wyżej przedstawionej propozycji Klemensowej, stawiając akcent na doskonałą formację religijną oraz moralno-intelektualną wychowawców, formację opartą na ścisłej więzi z Chrystusem. Z tej racji sądzi, że wychowawcami dzieci i młodzieży winni być, w pierwszym rzędzie rodzice chrześcijańscy oraz specjalnie dobrani opiekunowie i wychowawcy, tudzież służba i domownicy. Specjalną rolę w procesie formacyjnym, przyznaje przełożonym kościelnym. Świadczy o tym następujące zalecenie:

„Niech młodzieniec odwiedza często przełożonego Kościoła i słucha od niego pochwał dobrego życia" 74 .

Mając na uwadze skromne ramy niniejszego opracowania, skupimy się w dalszych paragrafach zasadniczo na ideałach pedagogicznych Klemensa Aleksandryjskiego, który w swych pismach przedstawia jednolitą i całościową wizję pedagogiki katolickiej.

${ }^{71}$ Clemens, Stromata VI 106, 2, GCS 52, 485, Niemirska-Pliszczyńska II 175.

72 Tamże VI 107, 3, GCS 52, 485, Niemirska-Pliszczyńska II 176.

73 Tamże VI 106, 2, GCS 52, 485, Niemirska-Pliszczyńska II 175.

74 Joannes Chrysostomus, De educandis liberis 83, SCh 188, 190, BOK 19, 102; por. tamże 22, $90,39,40,37,38,16$. 
5. Metody Bożej pedagogii. Mając na uwadze zasadę akomodacji oraz różnorodność ludzkich usposobień, Boski Przewodnik, zdaniem Klemensa, stosuje odrębne metody w stosunku do każdego ludzkiego indywiduum:

„Logos dostosowuje się odpowiednio do charakteru każdego człowieka: raz postępuje gwałtownie innym razem z pobłażliwością"75.

Z drugiej strony, mając na uwadze trzy wyżej wymienione grupy alumnów swej Szkoły, stosuje wobec kazdej z nich odpowiednie i skuteczne metody wychowawcze. Wobec:

a) Ludzi zatwardziałego serca - niewolników nałogów grzechowych, stosuje bądź kary i nagany, bądź zachęty i rady. Kara jest następstwem wyboru zła:

„Każdy z nas wybiera karę, kiedy dobrowolnie grzeszy. Wina jest tego, kto dokonuje wyboru, Bóg zaś winy nie ponosi" ${ }^{16}$.

Zagrożenie karą wyzwala obawę, która powstrzymuje od zła:

„Ci, którzy są trudni do wyleczenia, leczeni będą za pomocą groźby, zarzutu i nagany, tak jak żelazo jest obrabiane za pomocą ognia, młota i kowadła" ${ }^{\text {"77. }}$.

Mając na uwadze stopień surowości nagany, Klemens Aleksandryjski wylicza ich następujące rodzaje: „napomnienie”, ,narzekanie”, „krytyka”, „drwina”, „,zarzut”, ,zniewaga”, „ostre upomnienie” oraz „oskarżenie”78. Do środków pozytywnego oddziaływania należą: obietnice, zachęty i rady:

„Są trzy sposoby doradzania: pierwsze bierze przykłady z przeszłości, jak np., jaką karę ponieśli Żydzi, kiedy oddawali cześć złotemu cielcowi; jaką karę ponieśli, gdy oddawali się nierządowi, i inne podobne przykłady. Drugi jest uważnym przyglądaniem się sprawom obecnym [...]. Na sprawach przyszłych opiera się trzeci sposób dawania rady, który zachęca aby bacznie przyglądać się temu, co nadchodzi; toteż zostało powiedziane: ci, którzy popadają w grzechy, «zostaną wyrzuceni na zewnątrz w ciemności: tam będzie płacz i zgrzytanie zębów» ${ }^{79}$. Jest jeszcze inny rodzaj pedagogii - obietnica szczęścia. Przez Dawida mówi Pan: «Błogosławiony mąż, który nie zgrzeszył...»" $\$ 0$

b) Wierni słudzy. Na tym etapie środkiem motywującym dobre postępowanie jest idea posłuszeństwa oparta na autorytecie doskonałego Pedagoga,

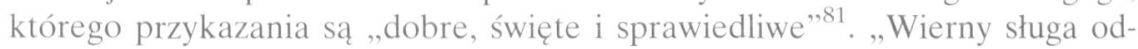

\footnotetext{
75 Clemens, Paedagogus I 66, 5, GCS 12, 129.

76 Tamże.

77 Tamże I 94, 1, GCS 12, 146.

78 Por. tamże I 76, 6-80, 2 .

79 Tamże I 90, 2-91, 1, GCS 12, 143; por. Mt 8, 12.

${ }^{80}$ Tamże I 92, 1, GCS 12, 144; por. Ps 1, 1-3.

81 Por. Clemens, Stromata III 84, 1.
} 
czuwa obawę przed Bogiem, swym Panem”82, „obawia się uchybić Ojcu”,83, którego kocha. Bojaźń Boża motywuje wierność Bożym nakazom, zawartym w przykazaniach:

„Przykazanie wyraża zakaz, zawieszając ze względów wychowawczych obawę nad głowami tych, którzy z kolei dzięki niej zastosują się do napomnienia" ${ }^{44}$.

Boski Pedagog skłania ,wiernego sługę” do posłuszeństwa przykazaniom, opartego na Bojaźni Bożej.

c) Przyjaciele Boga osiągają etap najwyższy na drodze doskonalenia, etap miłości doskonałej. Ta miłość, motywuje ich całe postępowanie. Przyjaciel Boga „nie podlega pożądaniom, ani jakimś pragnieniom, ani nie odczuwa braku czegokolwiek innego w zakresie duszy (gdyż ma wszystko), trwając poprzez miłość w zjednoczeniu z tym, który jest przedmiotem jego ukochania"85. Poprzez miłość doskonałą osiąga heroiczność cnót. Przyjaciel Boga „dzięki miłości znosi wszystko, wszystko wytrzymuje, nie dlatego, aby ludziom się podobać, lecz Bogu" "86. Wszystko, tzn. nie tylko śmierć męczeńską, ale różnego rodzaju prześladowania i represje, jak: pozbawienie praw obywatelskich, wygnanie, konfiskatę mienia, rzucenie na pożarcie zwierzętom, próbę mąk ogniowych ${ }^{87}$.

6. Program formacji intelektualnej oraz moralnej. Według Klemensa Aleksandryjskiego istnieją dwa zasadnicze źródła ludzkich błędów, które dają się sprowadzić do braków w zakresie formacji intelektualnej oraz braków w zakresie formacji moralnej:

„Z tych dwu braków w wypadku pierwszego nie uzyskują ludzie właściwego sądu, w przypadku drugiego - nie są w stanie podążać za tym sądem, który prawidłowo wyprowadzili [...]. Zgodnie z tym są do dyspozycji dwie odmienne zasady wychowawcze do każdego z dwu błędów" $"$.

Efektem finalnym obu wyżej wymienionych formacji jest miłość doskonała: „Obydwie te formacje współrosną do doskonałej miłości” ${ }^{\text {,O }}$.

a) Formacja intelektualna (pierwsza paideia). W ujęciu Klemensa Aleksandryjskiego składa się z czterech etapów, opisanych w jego dziele Stromateis:

\footnotetext{
82 Tamze I 173, 6, GCS 52, 107, Niemirska-Pliszczyńska I 19.

83 Tamze II 53, 4, GCS 52, 142, Niemirska-Pliszczyńska I 166

84 Tamze II 32, 3, GCS 52, 130, Niemirska-Pliszczyńska I 151.

85 Tamże VI 72, 1, GCS 52, 467, Niemirska-Pliszczyńska II 154.

86 Tamże VII 72, 2, GCS 52, 52, Niemirska-Pliszczyńska II 275.

87 Por. tamże IV 52, 3, GCS 52, 272, Niemirska-Pliszczyńska I 326.

88 Tamże VII 101, 6-102, 1, GCS 17, 71-72, Niemirska-Pliszczyńska II 301-302.

89 Tamże VII 102, 1, GCS 17, 72, Niemirska-Pliszczyńska II 302.
} 
- Wykształcenie ogólne, które obejmowało studium ośmiu przedmiotów: gramatyki, retoryki, geometrii, arytmetyki, astronomii, muzyki, harmonii oraz metryki. Przyjęła się ostatecznie liczba siedmiu przedmiotów (septem artes liberales). Przypisywany Alkuinowi podział artes liberales (nauk wyzwolonych) na trivium (gramatyka, retoryka, dialektyka) oraz quadrivium (arytmetyka, geometria, muzyka, astronomia) znany był już Augustynowi, Boecjuszowi oraz Izydorowi z Sewilli.

- Filozofia. Klemens Aleksandryjski kładzie akcent na studium filozofii „Zgodnej z Chrystusem”90. Jego zdaniem filozofia jest: „właściwą postawą wobec mądrości podanej przez Syna"91; ,gorliwym praktykowaniem mądrości”92; „poszukiwaniem prawdy" 93 ; ,wiedzą o samym dobru i prawdzie" 94 . Filozofia pełni ważną funkcję w formacji intelektualnej oraz moralnej: ,,jest współprzyczyną i czynnikiem współdziałającym w chwytaniu prawdy"95; „prowadzi do udziału w mądrości dzięki umiejętności wrażliwego postrzegania”, ", „uzdalnia do teoretycznego kontemplowania bytów”97; „ułatwia zrozumienie wszelkich zawiłości myślowych" "98; ,,pomaga temu, kto zapragnął uzyskać poznanie duchowe "99; , prowadzi do sprawiedliwości"100; , ,ukierunkowuje na dobro"101; „,czyni ludzi zacnymi i cnotliwymi”,102, , uczy powściągliwości”"103; , ,prowadzi do szczęścia przez cnotę"104. Ogólnie mówiąc "filozofia służy ulepszaniu duszy”105.

Bazyli Wielki mając na uwadze program kształcenia młodzieży poleca studium autorów klasycznych w tym poetów, historyków i filozofów, jako etap przygotowawczy do przyjęcia Ewangelii. Należy jednak stosować zasadę selekcji, przyjmując nauki dobre i budujące, a odrzucając złe i gorszące: „Zupełnie więc na podobieństwo pszczół powinniście korzystać z tych książek”; „musimy zwracać uwagę głównie na dzieła lub ich części, w których o cnocie jest mowa”; „,nie należy sięgać kolejno po wszystkie bez wyjątku dzieła, lecz tylko po te, które mogą nam przynieść pożytek" ${ }^{\text {106. }}$

\footnotetext{
${ }^{90}$ Por. tamże VI 67, 1.

91 Tamże VI 54, 1, GCS 52, 459, Niemirska-Pliszczyńska II 143.

92 Tamże I 30, 1, GCS 52, 19. Niemirska-Pliszczyńska I 22.

93 Tamże I 97, 1, GCS 52, 62, Niemirska-Pliszczyńska I 71.

94 Tamże I 93, 4, GCS 52, 60, Niemirska-Pliszczyńska I 68.

95 Tamże I 99, 1, GCS 52, 63, Niemirska-Pliszczyńska I 72.

96 Tamże VI 156, 1, GCS 52, 512, Niemirska-Pliszczyńska II 207.

97 Tamże VI 154, 4, GCS 52, 511, Niemirska-Pliszczyńska II 206.

98 Tamże I 20, 3, GCS 52, 14, Niemirska-Pliszczyńska I 15.

99 Tamże I 98, 2, GCS 52, 62, Niemirska-Pliszczyńska I 71

100 Tamże I 99, 3, GCS 52, 63, Niemirska-Pliszczyńska I 72.

101 Tamże VI 159, 8, GCS 52, 514, Niemirska-Pliszczyńska II 209.

102 Tamże VI 159, 6, GCS 52, 513, Niemirska-Pliszczyńska II 209.

103 Tamże II 110, 1, GCS 52, 173, Niemirska-Pliszczyńska I 202.

104 Tamże I 98, 2, GCS 52, 62, Niemirska-Pliszczyńska I 71.

105 Tamże VII 3, 2, GCS 17, 4, Niemirska-Pliszczyńska II 218.

106 Basilius, Ad adulescentes de legendis libris gentilium 2, 3, 5 PL 31, 565-577.
} 
- Mądrość. Alumni Szkoły Logosu winni upodabniać się do Boga przez udział w jego Mądrości. Klemens Aleksandryjski określa istotę mądrości prawdziwej oraz jej funkcje. Podmiotem mądrości jest Bóg i ci, „którzy zostali wyniesieni do bytu Boskiego"107. Przedmiotem mądrości jest „stałe i nienaruszalne poznanie oraz stałe i niezmienne zrozumienie spraw Boskich i ludzkich, obejmujące przeszłość, teraźniejszość i przyszłość" ${ }^{108}$. Źródłem mądrości jest to, co Syn objawił, czyli Stary i Nowy Testament oraz Słowo Boże żywe w Tradycji i nauce Kościoła ${ }^{109}$. Z tej racji Pismo Święte winno stać się przedmiotem nieustannych studiów, zgodnych z zasadami egzegezy Kościoła prawdziwego ${ }^{110}$. Mądrość prawdziwą należy odróżnić od „pseudomądrości" $" 11$.

- Poznanie misteryjne (mistyczne) - gnoza prawdziwa. Dotyczy poznania Boga i spraw Boskich, w stopniu najwyższym, dostępnym ludzkiej naturze; udziela go Boski Logos swym przyjaciołom:

,istotnie doskonała wiedza wznosi się ponad świat doczesny, zajmując się sprawami myślowymi oraz bardziej jeszcze duchowymi, których oko nie ujrzało, ani ucho nie słyszało i które nie dotarły do serca ludzi, dopóki nie udzielił nam wiedzy o nich sam Nauczyciel, odsłaniając co święte nad świętymi i coś świętsze od niego na wyższym jeszcze stopniu - ale tylko tym, którzy są dziedzicami synostwa Pańskiego w sposób prawdziwy, a nie domniemany"112.

To poznanie osiągane jest na etapie miłości doskonałej, określanej jako „miłość gnostyczna”"113. Gnoza prawdziwa ,,jest rodzajem doskonalenia się, które obejmuje zarówno sferę intelektualną jak i moralną" ${ }^{\text {"14. }}$. Doskonała miłość „,rodzi się pod wpływem gnozy" $" 15$ i przez nią się doskonali.

b) Formacja moralna (druga paideia). W ujęciu Klemensa Aleksandryjskiego, składa się również z czterech etapów, opisanych w Stromatach:

- Posłuszeństwo przykazaniom oparte na bojaźni Bożej ${ }^{116}$;

- Powściągliwość oparta na nadziei ${ }^{117}$;

- Ćwiczenie się w dobrym oparte na naśladowaniu dobroci Boga ${ }^{118}$;

107 Clemens, Stromata VI 125, 4, GCS 52, 495, Niemirska-Pliszczyńska II 188.

108 Tamże VI 61, 1, GCS 52, 462, Niemirska-Pliszczyńska II 147.

109 Por. tamze VI 54, 1; VII 92, 3.

110 Por. tamże VII 92, 3.

111 Por. tamże VII 98, 1.

112 Tamże VI 68, 1, GCS 52, 465-466, Niemirska-Pliszczyńska II 151; por 1 Kor 2, 9.

113 Por. tamże IV 130, 5.

114 Tamze VII 55, 1, GCS 17, 40, Niemirska-Pliszczyńska II 261.

115 Tamże VII 59, 4, GCS 17, 43, Niemirska-Pliszczyńska II 265.

116 Por. tamże II 55, 5; IV 108, 4.

117 Por. tamże III 4, 1; 57, 1; II 41, 1.

118 Por. tamże II 41, 3; 87, 2; III 54, 4; 56, 2 . 
- Pełne zespolenie woli z wolą Bożą - „Mądrość gnostyczna”119.

Z kolei Tertulian, w procesie formacji szczególną rolę przyznał sprawiedliwości, cierpliwości, miłosierdziu, niewinności oraz czystości ${ }^{120}$

Orygenes w 231 r. założył Szkołę w Cezarei Palestyńskiej. Jego uczeń, Grzegorz Cudotwórca, w Mowie pochwalnej na cześć Orygenesa ${ }^{121}$ opisał program tej Szkoły, obejmujący formację intelektualną, moralną i religijną: a) logika, dialektyka, geometria, astronomia oraz nauki przyrodnicze (,fizjologia”), których celem było ukazywanie działania Opatrzności; b) nabywanie cnót: powściągliwości, opanowania, roztropności, sprawiedliwości, męstwa, umiarkowania oraz pobożności, która jest „matką wszystkich cnót”; „pobożność stanowi początek a zarazem cel całego życia cnotliwego [...], ów cel polega na tym, by upodobniwszy się do Boga, dojść do Niego z czystym sercem i przy Nim już stale pozostać”; c) „studiowanie filozofii greckiej, w szczególności zasad etyki"; należy uwzględnić dzieła filozofów i poetów wszelkich szkół, którzy mówili o Bogu - byle nie ateistów; d) studium teologii oparte na alegorycznej egzegezie Pisma Świętego.

Hieronim kreśli natomiast program chrześcijańskiego wychowania dziewcząt, uwzględniając przede wszystkim formację religijno-moralną oraz intelektualną ${ }^{122}$.

- Bojaźń Boża - „Niech się uczy nie słuchać nic innego, nic innego nie mówić, tylko to, co należy do bojaźni Bożej";

- Nauka sztuki czytania i pisania;

- Częsty udział w nabożeństwach kościelnych;

- Studium Pisma Świętego oraz nauka łaciny i greki: „Niech codzienne odrabia pewne zadania z Pisma Świętego. Niech poznaje rytm greckich wierszy. Równocześnie z tym powinna iść nauka łaciny";

- „Niech się wystrzega wszelkich apokryfów”;

- „Niech się także uczy prząść wełnę, trzymać kądziel, obracać wrzeciono”;

- Należy unikać luksusu w ubiorze; odrzucić drogocenne ozdoby.

c) Paideia - wychowanie ku doskonałej miłości. „Miłość jest wspólnotą życia osób, między którymi istnieje jednomyślność w sprawach przynależnych do kręgu intelektualnego, moralnego oraz egzystencjalnego; jest wytrwałością w przyjaźni i serdeczności wraz z rozumną troską o potrzeby bliźnich" "123. Bóg, który jest miłością (1J 4, 16), jest Boską wspólnotą życia Ojca i Syna, i Ducha

119 Por. tamże IV 55, 3; 66, 2-3; 14, 3; 43, 2; 130, 5

120 Por. Tertullianus, De carne Christi 4.

121 Por. Gregorius Thaumaturgus, In Origenem oratio panegirica 7-8; 11, thum. S. Kalinkowski. ŹMT 11, 61-69.

122 Hieronymus, Epistula 107 (Ad Laetam de institutione filiae) 4-7; 9-12, CSEL 55, 290-305, tłum. J. Czuj II 403-412.

123 Clemens, Stromata II 41, 2, GCS 52, 134, Niemirska-Pliszczyńska I 157. 
Świętego. Przez wcielenie Syna Bożego, Boska wspólnota życia Trójcy Świętej przekształciła się w Bosko-ludzką wspólnotą życia, tj. w Kościół, który jest Szkołą Logosu.

Alumni tej Szkoły przez realizację programu kształcenia i wychowania dążą do uzyskiwania coraz większej jednomyślności (zgody) z Boskim Przewodnikiem - Głową Kościoła, w zakresie spraw przynależnych do kręgu intelektualnego (poznanie, przyjęcie Bożych kategorii myślenia) oraz moralno-egzystencjalnego (zgodność z wolą Bożą przez posłuszeństwo; postęp w dobrym nabywanie cnót). Realizacja procesu wychowawczego, prowadzi do wzrostu „zgody z Bogiem”. Stąd definicja cnoty:

„Cnota jest dyspozycją duszy, będącą w zgodzie z Logosem przez całe życie" 124 .

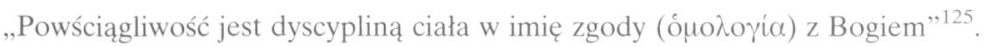

Cały proces formacji intelektualno-moralnej streszcza się w idei „upodobnienia":

„Naszym najwyższym celem jest upodobnienie ( $\grave{\xi} \xi o \mu o i ́ \omega \sigma \iota \varsigma)$ do prawdziwego Logosu" 126 .

Upodobnienie do Boga prowadzi do coraz większego poznania Boga i zjednoczenia. Mając to na uwadze Klemens Aleksandryjski stwierdza:

„Boska pedagogia ukazuje drogę prawdy prowadzącą do kontemplacji Boga"127.

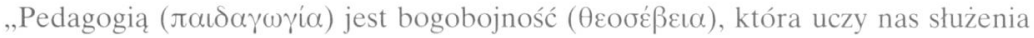
Bogu a zarazem wychowuje, byśmy poznali prawdę i mieli dobre usposobienie, prowadzące do nieba" 128 .

W zakończeniu warto zauważyć, że patrystyczna wizja pedagogiki katolickiej najpełniej i najbardziej klarownie, zarówno w ujęciu globalnym jak i szczegółowym, jawi się w doktrynie Klemensa Aleksandryjskiego. Pozostałe materiały źródłowe, zawarte zarówno w przekazach greckich jak i łacińskich ojców Kościoła, najczęściej o charakterze przyczynkowym, nie posiadają tej siły eks-

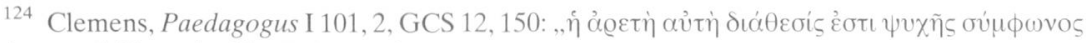

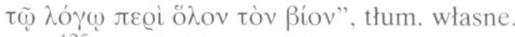

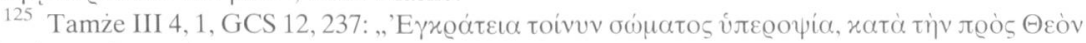

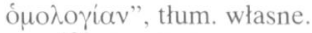

126 Tamże I 134, 2, GCS 12, 171.

127 Tamże I 54, 1, GCS 12, 122.

128 Tamże I 53, 3, GCS 12, 122. 
presji i wyrazistości, którą znajdujemy w myśli Aleksandryjczyka. Jest to wizja na wskroś teocentryczna i chrystocentryczna, co można już dostrzec w stosowanej onomastyce oraz terminologii pedagogicznej. Jest to ,pedagogia Boga”, „pedagogia Bożej mądrości”, ,pedagogia Chrystusa”, której celem jest „wychowanie Boże” „wychowanie w Chrystusie”.

Cały proces formacji pedagogicznej, w wymiarze globalnym, realizuje się w ramach wielkiej Bożej Instytucji, jaką jest Kościół - Szkoła Boskiego Logosu. Jest to więc wizja par excellence eklezjalna, w wymiarze uniwersalnym. Wychowankami tej Szkoły są nie tylko wszyscy wierzący, którzy przyjęli chrzest, ale również wszyscy ludzie „sprawiedliwi” - wszyscy ludzie dobrej woli. Jedynym i prawdziwym Kierownikiem tej Szkoły jest Odwieczne Słowo Ojca, Syn Boży, „Boski Przewodnik”, „Dobry Pasterz”, który prowadzi swoich alumnów na wyżyny świętości i doskonałości. Mając na uwadze różny stopień zaangażowania swych alumnów, na drodze doskonałości, Boski Logos pełni funkcję Lekarza, Wychowawcy i Nauczyciela w swojej Szkole. Udział w misji pedagogicznej Boskiego Logosu mają ci wszyscy, którzy osiągnęli status przyjaciół Boga. Mogą być nimi zarówno przedstawiciele hierarchii kościelnej, to jest biskupi, prezbiterzy i diakoni, jak i ci wszyscy przedstawiciele laikatu, którzy przez doskonałą miłość w pełni upodobnili się do Boskiego Logosu. Metody Boskiej Pedagogii są zróżnicowane i dostosowane do potrzeb indywidualnych poszczególnych grup wychowanków. Program formacji intelektualnej oraz moralnej oparty jest zarówno na Bożej mądrości przekazanej przez Logos Hellenom jak i na Słowie Objawionym w Starym i Nowym Testamencie. Pedagogia patrystyczna bazując na modelu wypracowanym przez starożytność przedchrześcijańską, dopełnia go i doskonali przez wartość chrześcijańskie; jest na wskroś logocentryczna (teocentryczna) i eklezjalna.

\section{DIE PÄDAGOGE GOTTES IN DEN SCHRIFTEN DER KIRCHENVÄTER}

(Zusammenfassung)

Die Hauptquellen der pädagogischen Lehre der Kirchenväter sind die Schriften von Clemens von Alexandria, Gregor Thaumaturgos (der Wundertäter), Basilius der Große, Tertullian, Hieronymus und Augustinus. Die gesamte Pädagogie finden wir in den Schriften des Clemens von Alexandria. Es ist hindurch christozentrische (logozentrische) und auch eklesiologische Vision. Der ganze Prozess der pädagogischen Formung realisiert sich in der Kirche - der Schule des göttlichen Logos, der für ihre Alumnen Arzt, Erzieher und Lehrer ist. Die Beteiligung an der 
Mission des Logos haben die „Freunden Gottes” (Gnostiker), die aus dem Kreis der Kirchenherrscher (Bischöfe, Presbyter und Diakonen) kommen und auch die Laiengläubigen.

In Rücksicht auf das Prinzip der Anpassung (Akkommodation) wendet göttlicher Logos verschiedene Methoden gegen einzelne Schüler (Zöglinge) an. Die Schüler in der Schule des Logos sind alle Gläubigen und alle „gerechten” Menschen ( die Menschen guter Wille). Das Ziel der intellektuellen und moralischen Formung (zwei Paideia), gegründet auf dem offenbarten Wort Gottes in der Heiligen Schrift und auf der mit dem Logos übereinstimmende Philosophie, ist völlige Angleichung und Verbindung mit dem Dreieinigen Gott in vollkommener Liebe. 